\title{
Ethics Regulation By The Accounting Profession
}

Joanne P. Healy-Burress, (jpburress@ hotmail.com), Ithaca College

\begin{abstract}
Because of recent accounting and management scandals, the accounting profession is under attack. Accountants have been accused of taking unethical actions such as overstating revenues. This paper examines the changes in ethical standards of the accounting profession in the United States and the role of ethics regulation by the State Boards of Accountancy. This research finds a difference in the ethical requirements across the 53 State Boards of Accountancy in the United States. Nineteen of the 53 Boards (35.8 percent) require no separate ethics testing. The increase in litigation and debate over ethical issues in recent years has failed to lead to an increase in separate ethics testing by the Boards. This finding could be attributed to the change in the Business Law section of the CPA exam. We find that some state Boards believe that ethics is now adequately being tested within the exam.
\end{abstract}

\section{Introduction}

Ethics is a code of conduct, a field of study, or a course of action, which applies to everyday life. Professional ethics is a code of conduct that applies to the ethical action of a profession. Recent audit failures have led some to conclude that there is unethical conduct within the accounting profession. For a number of years, the public accounting profession has been concerned with ethics. The purpose of this paper is to show the history and current status of ethics requirements by the accounting profession. Ethics regulation within the public accounting profession is undertaken by State Boards of Accountancy. However, several other organizations are concerned with public accountants' ethics. The Financial Accounting Standards Board has an effect, since CPAs must follow its Statements. The national organization for CPAs, the American Institute of Certified Public Accountants (AICPA), is involved through its Auditing Standards Board. The U.S. Securities and Exchange Commission, in its role of regulator of the federal securities laws, takes a great deal of interest in CPA ethics.

\section{Evolution Of The Code Of Ethics}

A professional code of conduct explicitly states the expectations of behavior and character for the members of the profession. The rules of conduct for the accounting profession can be traced back to the English Joint Stock Companies Act of 1844 as amended in 1856, which states that "The accounts of the company shall be examined and the correctness of the Balance Sheet ascertained by one or more auditors to be elected by the Company in General Meeting." [O'Riordan and Hirshfield, 1982, p. 30.]

Later in 1880, the English Institute of Chartered Accountants was inaugurated by Royal Charter from Queen Victoria. Its charter laid down certain "fundamental rules". These rules were the basis for the rules set forth by American accountants [O'Riordan and Hirshfield, 1982].

Progress in the area of accounting ethics was slow in the United States. In 1906 the constitution and bylaws of the American Association of Public Accountants (AAPA), the predecessor to the American Institute of Certified Public Accountants, contained no separate code of ethics. Article VII of the bylaws, under the heading, "Miscellaneous," contained the following two rules [Carey, 1969]. 
1. No member shall allow any person not being either a member of the Association or in partnership with himself as a public accountant to practice in his name as a public accountant.

2. No member shall directly or indirectly pay to any attorney, broker or agent any portion of his professional charges, nor accept any portion of the fees of any attorney, broker, or agent who may be concerned in any professional work in which such member is engaged.

Professional ethics was one of the major topics of the 1907 annual meeting. At this time, the bylaws were amended to introduce an article headed "Professional Ethics". Three rules were added to the existing two rules in the bylaws. [Carey, 1969].

3. No member shall engage in any business or occupation conjointly with that of a public accountant, which in the opinion of the Board of Trustees is incompatible or inconsistent therewith.

4. No member shall certify to exhibits, statements, schedules, or other form of accountancy work, the preparation of which was not carried on entirely under the supervision of himself, a member of his firm, one of his staff, a member of this Association or of similar Association of good standing in foreign countries.

5. No member shall in his business advertisements use any initials as an affix to his name that is not either authorized by statutory enactment of this country or by the well-known associations established for a similar purpose in the British Empire, nor shall he affiliate or substantially recognize any society that is designated or in any way sets itself out to be a so-called certified public accountant society, without the state in which such society is organized having the requisite statutory enactment in full force and effect.

The AAPA was virtually powerless to enforce these rules. For the most part, discipline of Association members had to be enforced by the state societies which were also relatively weak.

In 1916, the Institute of Certified Public Accountants was formed. They took no time in addressing the issue of ethics. In April, 1917 at the first regular meeting of the Council after the reorganization, eight rules of conduct were approved by the committee, covering the following topics [Carey, 1969].

1. Use of the title "Members of the American Institute of Accountants"

2. Certification of statements containing essential misstatements of fact or omissions

3. Practice by others in the name of a member

4. Commissions or brokerages to or from the laity

5. Occupations incompatible with the practice of public accounting

6. Certification of statements not prepared under satisfactory supervision

7. Notice to the Institute of participation in efforts to secure legislation

8. Solicitation of clients of other members

In 1917, two cases were heard by the Council sitting as a Trial Board. The two members were suspended for thirty days, setting an important precedent: the rules of conduct were to be enforced [Carey, 1969].

\section{The Contemporary Situation}

In October, 1983, Rholan E. Larson, then chairman of the AICPA, appointed a special committee to study the relevance and effectiveness of the professional standards (Anderson, 1985, p. 91). The AICPA Code of Professional Ethics at that time consisted of 13 rules of conduct and the interpretations and ethics rulings derived from them which were accepted by members as a guide to appropriate behavior.

As a result of their work, the Committee recommended a change in the structure of the Institute's Code of Professional Ethics. The revised Code adopted January 12, 1988 and amended January 14, 1992 consists of two basic sections:

1. Standards of Professional Conduct, which state the ethical responsibilities of AICPA members. 
2. Rules of Performance and Behavior, which consist of the rules of conduct. [AICPA, 1986].

One major difference between the previous code and the revised code was that the revised code applied to all AICPA members and not just to those in public accounting. Under the previous code, members who were not involved in public accounting were exempt from all but two of the rules. They were required to comply only with Rule 102 "Objectivity and Integrity" and Rule 501 "Acts Discreditable to the Profession." One can reflect upon the implications of this exemption by noting the following composition of the membership of the AICPA:

$\begin{array}{lrr} & 1980^{1} & \underline{2001^{2}} \\ \text { Public accounting practice } & 53.8 \% & 38.9 \% \\ \text { Industrial } & 36.1 \% & 46.6 \% \\ \text { Government } & 3.3 \% & 4.1 \% \\ \text { Education } & 2.6 \% & 2.3 \% \\ \text { Other } & 4.2 \% & 8.1 \%\end{array}$

Thus, $46.2 \%$ of the AICPA membership in November 1980 was exempted from all but two of the rules contained in the previous Code or Professional Ethics. This exclusion was understandable since most of the other rules pertained specifically to public accounting situations. However, this situation left the profession open to criticism in terms of fulfilling its monitoring function. The revised code was to be a goal-oriented code setting forth the principles that would guide members to make the appropriate decisions. The revised code eliminated this problem because all AICPA members were required to comply with the revised code.

The revised code provided a mandatory quality assurance review program (QAR) to monitor practice. The purpose of the QAR committee was to uncover deviations from technical or ethical standards before they became the subject of complaints or news stories. The QAR program dealt with firms in public practice. Most surprising, members of the AICPA in public practice would be required to work only in firms that participate in the QAR program. The AICPA administered the program in the states that did not set up a QAR program. The special committee also recommended a mandatory continuing professional education program for all members, exempting those retired or not actively engaging in the profession [Anderson, 1985, p. 98].

All members of the AICPA must adhere to the new Code. However, this does not mean that CPAs currently know the content of the Code, or that they can apply the content to make the appropriate decision. Some states test new CPAs by requiring an ethics exam or course before issuing a license.

In spite of these improvements, accountants and accounting firms have come under attack recently because of high-profile accounting scandals such as those involved at Enron or WorldCom. The Sarbanes-Oxley Act was signed into law in July of 2002 by President Bush. One of several requirements of this Act is that publicly traded firms disclose whether they have a Code of Ethics or Code of Conduct for their senior executives. Accountants may be faced with the job of helping firms comply with this requirement. Although many firms already have a code of ethics, accountants may be asked to review and revise the codes [Myers, 2003, p. 30].

\section{Methodology}

The ethics testing requirements by the State Boards of Accountancy were examined for three time periods, 1986, 1996, and 2002. A questionnaire (Exhibit 1) was mailed in February, 1986 to the Board of Accountancy of all 50 states, the District of Columbia, Guam, and Puerto Rico. The survey was to determine the extent of ethics testing for CPAs in each jurisdiction. After second mailings, 47 of 53 jurisdictions responded (88.7 percent). The ethics requirements for 1996 and 2002 are from Gleim's CPA Review: A System for Success.

\footnotetext{
${ }^{1}$ Merz and Groebner, 1982 p. 45.

${ }^{2} 2001$ AICPA Annual Financial Report.
} 


\section{Results of the survey}

The questionnaire showed that 30 of the 47 responding (63.8 percent) required some form of exam or course in ethics before issuing a CPA license (Column 2 of Exhibit 2). The exam or course most frequently used was the AICPA's "Professional Ethics for Certified Public Accountants" prepared by the California Certified Public Accountants Foundation for Education and Research. The course was a self-study, open book exam. One state which reported no ethics exam in 1980 was West Virginia had discontinued ethics testing. West Virginia reported that until 1972, they required an open book ethics exam.

Question 4 (Exhibit 1) asked what the Board's reasons were for requiring the exam or course. The most common reasons given for requiring an additional exam or course were as follows:

1. A CPA should be aware of the rules of ethics of the profession.

2. It is an area not sufficiently covered by school curricula.

3. In the case of a later violation by the licensee of the ethical rules, it could not be said that the licensee was not familiar with the ethical rules (at least at a given point in time).

4. To protect the Board and the newly certified accountants.

Of the 17 states not requiring an ethics exam or course, Vermont replied that the requirement would go into effect June 30, 1986 and North Carolina replied that they were looking into it. The most frequent reason a separate exam or course was not given was "that the state board felt the material was already adequately covered."

\section{The current status of ethics testing}

The third column of Exhibit 2 is a summary of the status of ethics testing by State Boards of Accountancy as of May 1996. Of the 53 State Boards of Accountancy 21 (39.6 percent) do not require a separate ethics exam either at the time of the CPA testing or at the time of certification. In 1986, North Carolina had replied that they were looking into an ethics test requirement and in fact now have a separate ethics exam requirement.

One very interesting finding was that two states, Alabama and South Carolina discontinued their ethics testing requirement. Phone calls were made to both the Alabama and the South Carolina Boards of Accountancy to inquire as to why ethics testing was discontinued. Alabama reported that they discontinued testing ethics separately when the Business Law Section was changed to Business Law and Professional Responsibilities effective May, 1994. The Alabama State Board of Accountancy felt that enough ethics is covered in the new section and it is less costly and easier to administer. The South Carolina Board of Accountancy discontinued ethics testing in April, 1992. They reported that they felt that there were differences between the South Carolina Code and the AICPA Code. They now require applicants to read the South Carolina Code of Ethics and sign a statement stating that they agree with the South Carolina Code.

The fourth column reports the status of ethics testing in 2001. Although the accounting profession has come under recent criticism, there is very little difference since 1996 with the exception of Alabama and Illinois. Both Alabama and Illinois now require an ethics exam. As of 2001, 19 of the 53 (35.8 percent) State Boards of Accountancy still do not require separate ethics exams.

\section{Conclusion}

The standard of ethical conduct of the accounting profession has been an issue for several years. This paper presents the development of ethics regulation of the accounting profession and culminates in a discussion of the current status of the ethics requirements by each of the Boards of Accountancy of the United States.

Prior to 1983, concern over ethical issues had primarily been limited to accountants in public practice. Management accountants had gone unnoticed. However, more recently it has become evident that both public and management accountants face important ethical decisions. 
The growing concern and public debate over accounting ethics have led many of the State Boards of Accountancy to require a separate ethics exam. However, in the last fifteen years little has been done by the State Boards of Accountancy to improve ethical standards. Although 34 of the 53 (64.2 percent) of the Boards of Accountancy now require a separate ethics exam before a certificate is issued, the testing is done only once during the accountant's career. The AICPA website was examined for two things. First, an examination of the composition of the AICPA membership in 2001 was done. The results showed that $34.1 \%$ of the members of the AICPA are from states which require no ethics testing. Second, the number of disciplinary actions per state was tabulated. In 2002, 37\% of the disciplinary actions were on members from states which require no ethics testing. It appears that ethics testing by state boards has had very little impact on the number of disciplinary actions in the state.

Today's "Code of Professional Conduct" helps eliminate some of these problems. Firms in public practice are continually monitored. The mandatory professional education requirement helps insure that members continue to perform with competence, integrity, and objectivity. However, recent accounting and management scandals have proved that it is not enough and the Sarbanes-Oxley Act has resulted.

An important implication of this research is that accountants themselves may still be able to make improvements. Including more ethics education in college curricula and additional testing by State Boards of Accountancy may be indicated.

\section{References}

1. American Institute of Certified Public Accountants, Report of the Special Committee on Standards of Professional Conduct for Certified Public Accountants, Restructuring Professional Standards to Achieve Professional Excellence in a Changing Environment, (New York: American Institute of CPAs, 1986).

2. American Institute of Certified Public Accountants, 1992, Code of Professional Conduct, AICPA Professional Standards, New York: Commerce Clearing House, Inc.

3. American Institute of Certified Public Accountants, 2003, website: www.aicpa.org.

4. Anderson, G. D., 1985, "A Fresh Look at Standards of Professional Conduct," Journal of Accountancy, Sept., pp. 91-106.

5. Carey, J. L., 1969, The Rise of the Accounting Profession From Technician to Professional 1896 - 1936, (American Institute of Certified Public Accountants, Inc. 1969).

6. $\quad$ Davis, R. R., 1984, "Ethical Behavior Reexamined," The CPA Journal, Dec., pp. 32-36.

7. Gleim, I. N., 1995, CPA Review: A System for Success, 1995-1996 edition, p. 9.

8. $\quad$ Gleim, I. N., 2001, CPA Review: A System for Success, 2001-2002 edition, p. 9.

9. Merz, M. C., and D. F. Groebner, 1982, "Ethics and the CPA in Industry," Management Accountant, Sept. pp. 44-48.

10. Myers, R., 2003, “Ensuring Ethical Effectiveness,” Journal of Accountancy, Feb. pp. 28-33.

11. O'Riordan, M., and A. S. Hirshfield, 1982, "Aspects of the Profession's Code of Ethics," The CPA Journal, Aug. pp.30-33. 


\section{Exhibit 1 \\ Ethics Questionnaire}

1. Do you currently require an ethics course? (If your answer is "yes", answer questions 2, 3, and 4. If your answer is "no", answer questions 5, 6, 7, 8, and 9.)

2. What is the name of the required course?

3. When did the requirement go into effect?

4. What were your reasons for requiring the course?

5. Do you expect to require an ethics course in the future?

If your answer to question 5 is "no" answer question 6, otherwise go to question 7.

6. Why do you think an ethics course should not be required?

7. What would be your reasons for requiring an ethics course?

8. Which ethics course would you require?

9. When would the requirement go into effect? 
Exhibit 2

Ethics Requirements By State

\begin{tabular}{|c|c|c|c|}
\hline STATE & $\begin{array}{l}1986 \text { QUESTIONAIRE } \\
\text { RESPONSE }\end{array}$ & $\begin{array}{l}\text { REQUIREMENTS AS OF MAY } \\
1996^{1}\end{array}$ & $\begin{array}{l}\text { REQUIREMEN } \\
2002^{2}\end{array}$ \\
\hline Alabama & $\begin{array}{l}\text { Requires the AICPA's "Professional } \\
\text { Ethics for Certified Public Accountants" }\end{array}$ & No ethics test requirement & $\begin{array}{l}\text { Ethics test requi } \\
\text { certification }\end{array}$ \\
\hline Alaska & No Response & Separate ethics test is given & Separate ethics t \\
\hline Arizona & $\begin{array}{l}\text { Requires the AICPA's "Professional } \\
\text { Ethics for Certified Accountants" }\end{array}$ & Ethics test required at the time of certification & $\begin{array}{l}\text { Ethics test requi } \\
\text { certification }\end{array}$ \\
\hline Arkansas & No ethics test requirement & No ethics test requirement & No ethics test re \\
\hline California & $\begin{array}{l}\text { Ethics test required. (The name of the test } \\
\text { was not provided.) }\end{array}$ & Separate ethics test is given & Separate ethics \\
\hline Colorado & $\begin{array}{l}\text { Requires the AICPA's "Professional } \\
\text { Ethics for Certified Public Accountants" }\end{array}$ & Ethics test required at the time of certification & $\begin{array}{l}\text { Ethics test requi } \\
\text { certification }\end{array}$ \\
\hline Connecticut & $\begin{array}{l}\text { Requires the AICPA's "Professional } \\
\text { Ethics for Certified Public Accountants" }\end{array}$ & Ethics test required at the time of certification & $\begin{array}{l}\text { Ethics test requi } \\
\text { certification }\end{array}$ \\
\hline Delaware & $\begin{array}{l}\text { Requires the AICPA's "Professional } \\
\text { Ethics for Certified Public Accountants" }\end{array}$ & Ethics test required at the time of certification & $\begin{array}{l}\text { Ethics test requi } \\
\text { certification }\end{array}$ \\
\hline D. C. & No Response & No ethics test requirement & No ethics test re \\
\hline Florida & $\begin{array}{l}\text { Requires licensees to pass an examination } \\
\text { on the law and rules relating to the } \\
\text { practice of public accounting }\end{array}$ & Separate ethics test given & Separate ethics \\
\hline Georgia & No ethics test requirement & No ethics test requirement & No ethics test re \\
\hline Guam & No ethics test requirement & No ethics test requirement & No ethics test re \\
\hline Hawaii & No ethics test requirement & No ethics test requirement & No ethics test re \\
\hline Idaho & $\begin{array}{l}\text { Requires the AICPA's "Professional } \\
\text { Ethics for Certified Public Accountants" }\end{array}$ & Separate ethics test is given & Separate ethics \\
\hline Illinois & No ethics test requirement & No ethics test requirement & Separate ethics \\
\hline Indiana & No Response & No ethics test requirement & No ethics test re \\
\hline Iowa & $\begin{array}{l}\text { Requires the AICPA's "Professional } \\
\text { Ethics for Certified Public Accountants" }\end{array}$ & Separate ethics test is given & Separate ethics \\
\hline Kansas & $\begin{array}{l}\text { Requires the AICPA's "Professional } \\
\text { Ethics for Certified Public Accountants" }\end{array}$ & Separate ethics test is given & Separate ethics \\
\hline Kentucky & Requires an open book handwritten exam & Ethics test required at the time of certification & $\begin{array}{l}\text { Ethics test requi } \\
\text { certification }\end{array}$ \\
\hline Louisiana & No ethics test requirement & No ethics test requirement & No ethics test re \\
\hline Maine & No ethics test requirement & No ethics test requirement & No ethics test re \\
\hline Maryland & $\begin{array}{l}\text { Requires the AICPA's "Professional } \\
\text { Ethics for Certified Public Accountants" }\end{array}$ & Separate ethics test is given & Separate ethics \\
\hline Massachusetts & No ethics test requirement & No ethics test requirement & No ethics test re \\
\hline Michigan & No ethics test requirement & No ethics test requirement & No ethics test re \\
\hline Minnesota & $\begin{array}{l}\text { Open book test on State Rules and } \\
\text { Statutes prior to certification }\end{array}$ & Separate ethics test is given & Separate ethics \\
\hline Mississippi & No ethics test requirement & No ethics test requirement & No ethics test re \\
\hline Missouri & $\begin{array}{l}\text { Requires the AICPA's "Professional } \\
\text { Ethics for Certified Public Accountants" }\end{array}$ & Ethics test required at the time of certification & $\begin{array}{l}\text { Ethics test requi } \\
\text { certification }\end{array}$ \\
\hline Montana & $\begin{array}{l}\text { Requires the AICPA's "Professional } \\
\text { Ethics for Certified Public Accountants" }\end{array}$ & Ethics test required at the time of certification & $\begin{array}{l}\text { Ethics test requi } \\
\text { certification }\end{array}$ \\
\hline Nebraska & $\begin{array}{l}\text { Requires the AICPA's "Professional } \\
\text { Ethics for Certified Public Accountants" }\end{array}$ & Ethics test required at the time of certification & $\begin{array}{l}\text { Ethics test requi } \\
\text { certification }\end{array}$ \\
\hline
\end{tabular}




\begin{tabular}{|c|c|c|c|}
\hline Nevada & $\begin{array}{l}\text { The most commonly utilized ethics exam } \\
\text { is "Professional Ethics" self study course: } \\
\text { as sponsored by the California CPA } \\
\text { Foundation. We will accept the other } \\
\text { ethics courses sponsored by other state } \\
\text { societies. }\end{array}$ & Ethics test required at the time of certification & $\begin{array}{l}\text { Ethics test requi } \\
\text { certification }\end{array}$ \\
\hline New Hampshire & No Response & No ethics test requirement & No ethics test re \\
\hline New Jersey & No ethics test requirement & No ethics test requirement & No ethics test re \\
\hline New Mexico & $\begin{array}{l}\text { Requires the California Professional } \\
\text { Ethics Exam }\end{array}$ & Separate ethics test is given & Separate ethics $\mathrm{t}$ \\
\hline New York & No ethics test requirement & No ethics test requirement & No ethics test re \\
\hline North Carolina & Under study by the board and association & Separate ethics test is given & Separate ethics $\mathrm{t}$ \\
\hline North Dakota & $\begin{array}{l}\text { Requires the AICPA's "Professional } \\
\text { Ethics for Certified Public Accountants" }\end{array}$ & Separate ethics test is given & Separate ethics $\mathrm{t}$ \\
\hline Ohio & $\begin{array}{l}\text { Requires the AICPA's "Professional } \\
\text { Ethics for Certified Public Accountants" }\end{array}$ & Separate ethics test is given & Separate ethics $\mathrm{t}$ \\
\hline Oklahoma & No ethics test requirement & No ethics test requirement & No ethics test re \\
\hline Oregon & $\begin{array}{l}\text { Requires the AICPA's "Professional } \\
\text { Ethics for Certified Public Accountants" } \\
\text { or the California Foundation of CPAs } \\
\text { Exam }\end{array}$ & Ethics test required at the time of certification & $\begin{array}{l}\text { Ethics test requi } \\
\text { certification }\end{array}$ \\
\hline Pennsylvania & No ethics test requirement & No ethics test requirement & No ethics test re \\
\hline Puerto Rico & No Response & No ethics test requirement & No ethics test re \\
\hline Rhode Island & $\begin{array}{l}\text { Requires the AICPA's "Professional } \\
\text { Ethics for Certified Public Accountants" }\end{array}$ & Ethics test required at the time of certification & $\begin{array}{l}\text { Ethics test requi } \\
\text { certification }\end{array}$ \\
\hline South Carolina & $\begin{array}{l}\text { Requires the AICPA's "Professional } \\
\text { Ethics for Certified Public Accountants" }\end{array}$ & No ethics test requirement & No ethics test re \\
\hline South Dakota & $\begin{array}{l}\text { Requires the AICPA's "Professional } \\
\text { Ethics for Certified Public Accountants" }\end{array}$ & Separate ethics test is given & Separate ethics \\
\hline Tennessee & $\begin{array}{l}\text { Requires the AICPA's "Professional } \\
\text { Ethics for Certified Public Accountants" }\end{array}$ & Separate ethics test is given & Separate ethics \\
\hline Texas & $\begin{array}{l}\text { Required to complete an ethics test } \\
\text { provided by the Board prior to receiving } \\
\text { the certificate }\end{array}$ & Ethics test required at the time of certification & $\begin{array}{l}\text { Ethics test requi } \\
\text { certification }\end{array}$ \\
\hline Utah & Required to pass an exam on Board ethics & Separate ethics test is given & Separate ethics t \\
\hline Vermont & $\begin{array}{l}\text { Requirement will go into effect June } 30 \text {, } \\
\text { 1986. The exam had not been selected at } \\
\text { the time of the questionnaire. }\end{array}$ & Separate ethics test is given & Separate ethics $\mathrm{t}$ \\
\hline Virginia & No Response & Separate ethics test is given & Separate ethics $\mathrm{t}$ \\
\hline Washington & $\begin{array}{l}\text { Requires the AICPA's "Professional } \\
\text { Ethics for Certified Public Accountants" }\end{array}$ & Ethics test required at the time of certification & $\begin{array}{l}\text { Ethics test is req } \\
\text { certification }\end{array}$ \\
\hline West Virginia & No ethics test requirement & No ethics test requirement & No ethics test re \\
\hline Wisconsin & Open book ethics examination required & Separate ethics test is given & Separate ethics t \\
\hline Wyoming & $\begin{array}{l}\text { Requires the AICPA's "Professional } \\
\text { Ethics for Certified Public Accountants" }\end{array}$ & Separate ethics test is given & Separate ethics \\
\hline
\end{tabular}


$\underline{\text { Notes }}$ 